\title{
Uji efek ekstrak buah okra (Abelmoschus esculentus) terhadap kadar glukosa darah pada tikus wistar (Rattus norvegicus) yang diinduksi aloksan
}

\author{
${ }^{1}$ Leonardus B. A. Prakoso \\ ${ }^{2}$ Christi Mambo \\ ${ }^{3}$ Mona P. Wowor
}

\author{
${ }^{1}$ Kandidat Skripsi Fakultas Kedokteran Universitas Sam Ratulangi Manado \\ ${ }^{2}$ Bagian Farmakologi dan Terapi Fakultas Kedokteran Universitas Sam Ratulangi \\ Email: bayu.prakosooo@gmail.com
}

\begin{abstract}
Okra (Abelmoschus esculentus) is one of many herbal medicine that have been used worldwide to prevent and treat diabetes mellitus. This research aimed to evaluate the effect of garlic bulbs extract administration on elevated blood glucose levels on Wistar rats ( $R$. norvegicus) induced by alloxan. The subject in this research were male Wistar rats with total of 15 samples divided into 5 groups, consisting of one negative control group, one positive control group who were induce by $130 \mathrm{mg} / \mathrm{kgBW}$ of alloxan that cause the Rats in conditions of hyperglycemic, and three groups of Rats were given okra extract with dose of $0.375 \mathrm{ml} / 100 \mathrm{gBW}$ of rat, $0.75 \mathrm{ml} / 100 \mathrm{gBW}$ of rat, and $1.5 \mathrm{ml} / 100 \mathrm{gBW}$ of rat. Blood glucose levels was measured on day zero, day one and day two every thirty minutes on 0,30 , $60,90,120$, and every six hours on $0,6,12,18$, and 24 . Data from the measurement showed that $0.375 \mathrm{ml} / 100 \mathrm{gBW}, 0.75 \mathrm{ml} / 100 \mathrm{gBW}$, and $1.5 \mathrm{ml} / 100 \mathrm{gBW}$ of okra extract can't reduce elevated blood glucose levels on Wistar rats.
\end{abstract}

Keywords: Abelmoschus esculentus, okra, blood glucose levels, alloxan

\begin{abstract}
Abstrak: Buah Okra (Abelmoschus esculentus) diyakini masyarakat sebagai salah satu tanaman obat yang mampu mencegah dan mengobati penyakit diabetes. Penelitian ini bertujuan untuk menguji apakah pemberian ekstrak buah okra dapat menurunkan kadar glukosa darah tikus Wistar ( $R$. norvegicus) yang diinduksi aloksan. Subjek penelitian berupa tikus Wistar berjumlah 15 ekor yang dibagi dalam 5 kelompok, terdiri atas satu kelompok kontrol negatif, satu kelompok kontrol positif yang diberi aloksan dengan dosis 130 $\mathrm{mg} / \mathrm{kgBB}$ yang menyebabkan tikus Wistar dalam keadaan hiperglikemik yang kemudian diinsuksi insulin, dan tiga kelompok Tikus hiperglikemik diberi ekstrak buah okra dengan dosis $0,375 \mathrm{ml} / 100 \mathrm{gBB}$ tikus, $0,75 \mathrm{ml} / 100 \mathrm{gBB}$ tikus, dan $1,5 \mathrm{ml} / 100 \mathrm{gBB}$ tikus. Data diperoleh dari pemeriksaan kadar glukosa darah pada semua kelompok tikus Wistar pada hari ke nol, pertama, dan kedua pada menit ke-0, 30, 60, 90, 120 dan jam ke-0, 6, 12, 18, dan 24. Hasil penelitian menunjukkan bahwa pemberian ekstrak buah okra dengan dosis 0,375 $\mathrm{ml} / 100 \mathrm{gBB}$ tikus, $0,75 \mathrm{ml} / 100 \mathrm{gBB}$ tikus, dan $1,5 \mathrm{ml} / 100 \mathrm{gBB}$ tikus tidak mempunyai efek menurunkan kadar glukosa darah tikus Wistar.
\end{abstract}

Kata kunci: abelmoschus esculentus, buah okra, kadar glukosa darah, aloksan

Diabetes mellitus (DM) adalah suatu kelompok penyakit metabolik dengan karakteristik hiperglikemia yang terjadi karena kelainan sekresi insulin, kerja insulin atau kedua-duanya disertai dengan gangguan metabolisme karbohidrat, lipid dan protein sebagai akibat insufisiensi fungsi insulin. ${ }^{1}$ 
Menurut Konsensus Pengelolaan Diabetes Melitus di Indonesia, dari berbagai penelitian epidemiologis di Indonesia didapatkan prevalensi DM sebesar $1,5-2,3 \%$ pada penduduk usia lebih dari 15 tahun, bahkan pada suatu penelitian epidemiologis di Manado didapatkan prevalensi DM 6,1\%. Berdasarkan pola pertambahan penduduk tersebut, pada tahun 2020 nanti diperkirakan penderita DM akan meningkat hingga 178 juta penduduk. ${ }^{2}$

Data Lokakarya Nasional Tanaman Obat, Indonesia memiliki 30.000 jenis tumbuhan, termasuk diantaranya 940 jenis tumbuhan berkhasiat obat. Salah satunya adalah buah Okra (Abelmoschus esculentus). ${ }^{3}$ Di Ethiophia, buah okra dipercaya dapat menurunkan kadar glukosa darah pada penderita diabetes. ${ }^{4}$

\section{METODE PENELITIAN}

Jenis penelitian ini ialah eksperimental yang dilakukan sejak bulan Agustus 2016November 2016 di Laboratorium Farmakologi Fakultas Matematika dan Ilmu Pengetahuan Alam Universitas Sam Ratulangi Manado. Subjek penelitian terdiri dari 15 ekor tikus Wistar.

Alat yang digunakan dalam penelitian terdiri dari wadah plastik, kawat kasa, botol minuman, wadah makanan, oven, blender, corong pemisah, kertas saring, cawan petri, labu erlenmeyer, timbangan analitik, batang pengaduk, gelas ukur, glukometer, gunting, kapas, stopwatch, sonde lambung, dan semprit $1 \mathrm{cc}$. Bahan yang digunakan terdiri dari buah okra, etanol $96 \%$, aloksan, analog insulin, aquades, dan pakan AD2.

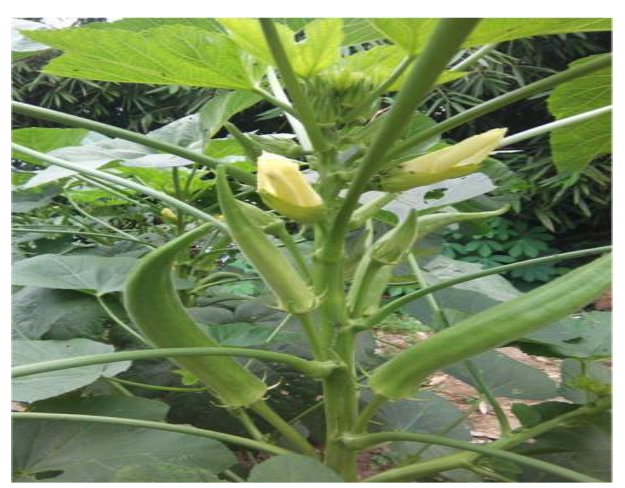

Gambar 1. Buah okra
Hewan uji dibagi dalam lima kelompok. Sebelum pengukuran pada hari ke nol, semua tikus dipuasakan selama 24 jam. Setelah 24 jam kadar glukosa darah puasa semua tikus diperiksa (H0), setelah itu satu kelompok tikus hanya diberikan aquades sedangkan empat kelompok tikus diberikan aloksan dengan dosis 130 $\mathrm{mg} / \mathrm{kgBB}$ tikus untuk merusakan sel B pankreas sehingga glukosa darah tikus meningkat. Kadar glukosa darah semua tikus diperiksa kembali pada hari pertama (H1) setelah 24 jam pemberian aloksan. Setelah kadar glukosa darah diukur, semua kelompok tikus diberikan perlakuan. Kelompok kontrol positif diberikan analog insulin dengan dosis 0,4 IU/100 gBB tikus, dan tiga kelompok lain diberikan ekstrak buah okra dengan dosis $0,375 \mathrm{mg} / 100 \mathrm{gBB}$ tikus, $0,75 \mathrm{mg} / 100 \mathrm{gBB}$ tikus, dan 1,5 mg/100 gBB tikus. Kadar glukosa darah pada semua tikus kemudian diperiksa pada pada menit ke-0, 30, 60, 90, 120 dan jam ke-0, 6, 12, 18, dan 24. Semua sampel darah diambil dari pemotongan ujung ekor tikus dan kadar glukosa darah diukur dengan glukometer.

Penelitian ini menggunakan aloksan dengan dosis $130 \mathrm{mg} / \mathrm{kgBB}$. Aloksan diberikan secara intraperitoneal pada perut tikus bagian bawah.

Untuk penentuan dosis dan pemberian analog insulin dipakai patokan berat badan rata-rata manusia dewasa di Indonesia adalah $60 \mathrm{~kg}$. Dosis yang digunakan untuk manusia dewasa yang memiliki kadar glukosa darah $>180 \mathrm{mg} / \mathrm{dL}$ adalah 6 IU novomix. Perhitungan pemberian dosis berdasarkan pada rumus Human Equivalent Dose (HED) based on Body Surface Area (BSA). ${ }^{5}$

$\mathrm{HED}(\mathrm{U} / \mathrm{kg})=6 \mathrm{IU} / 60 \mathrm{~kg}=0,1 \mathrm{IU} / \mathrm{kg}$

HED $(\mathrm{U} / \mathrm{kg})=$ animal dose $(\mathrm{mg} / \mathrm{kg}) \mathrm{x}$ animal $\mathrm{Km}$

human $\mathrm{Km}$

Animal dose $(\mathrm{U} / \mathrm{kg})=0,1 \mathrm{IU} \times \frac{37}{6}$

$=0,6 \mathrm{IU} / 150 \mathrm{grBB}$

$=0,4 \mathrm{IU} / 100 \mathrm{grBB}$

Analog insulin diberikan secara intraperitoneal pada perut tikus. 
Buah okra yang sudah dikeringkan di oven dihaluskan dengan menggunakan blender. Sebanyak 173,4 gram tepung buah okra diekstraksi dengan cara maserasi menggunakan $1000 \mathrm{ml}$ etanol 96\%. Setelah dimaserasi selama 5 hari (setiap hari diaduk), hasil larutan disaring menggunakan kertas saring, didapatkan filtra. Filtrat kemudian ditempatkan dalam labu erlenmeyer dan diuapkan sampai didapatkan ekstrak pekat sebanyak 20,46 gram. Ekstrak inilah yang digunakan dalam penelitian.

Dosis ekstrak buah okra pada penelitian ini ialah $75 \mathrm{mg} / \mathrm{kgBB} / \mathrm{hari}, \quad 150$ $\mathrm{mg} / \mathrm{kgBB} /$ hari, dan $300 \mathrm{mg} / \mathrm{kgBB} /$ hari. Jika dosis sediaan ekstrak sebanyak $1000 \mathrm{mg}$ dilarutkan dalam $50 \mathrm{ml}$ aquades, maka didapatkan dosis sebagai berikut:
1. $\frac{75 \mathrm{mg}}{1000 \mathrm{mg}} \times 50 \mathrm{ml}=3,75 \mathrm{ml} / \mathrm{kg}$ $\mathrm{BB} /$ hari

2. $\frac{150 \mathrm{mg}}{1000 \mathrm{mg}} \times 50 \mathrm{ml}=7,5 \mathrm{ml} / \mathrm{kg} \mathrm{BB} /$ hari

3. $\frac{300 \mathrm{mg}}{1000 \mathrm{mg}} \times 50 \mathrm{ml}=1,5 \mathrm{ml} / \mathrm{kg} \mathrm{BB} /$ hari

Untuk tikus dengan BB sekitar 100 gram, diberikan dosis: 1) $0,375 \mathrm{ml} / 100$ grBB/hari; 2) $0,75 \mathrm{ml} / 100 \mathrm{grBB} / \mathrm{hari}$; dan

\section{3) $1,5 \mathrm{ml} / 100 \mathrm{grBB} / \mathrm{hari}$}

Dosis ekstrak yang digunakan yaitu 75 $\mathrm{mg} / \mathrm{kgBB}$ tikus dengan volume pemberian $0,375 \mathrm{ml}, 150 \mathrm{mg} / \mathrm{kgBB}$ tikus dengan volume pemberian $0,75 \mathrm{ml}$, dan 300 $\mathrm{mg} / \mathrm{kgBB}$ dengan volume pemberian 1,5 ml. Ekstrak diberikan secara oral dengan menggunakan sonde lambung dan semprit.

\section{HASIL PENELITIAN}

Pengukuran kadar glukosa darah dilakukan sebanyak 11 kali yaitu hari ke nol (H0), hari pertama $(\mathrm{H} 1)$, hari kedua (H2) pada menit ke-0, 30, 60, 90, 120 dan jam ke-0, 6, 12, 18, dan 24 setelah perlakuan. Kelompok satu (K1) merupakan kelompok kontrol negatif yaitu kelompok yang hanya diberikan aquades, kelompok dua (K2) merupakan kelompok kontrol positif yaitu kelompok yang diberikan aloksan dan analog insulin, kelompok tiga (K3), kelompok empat (K4), dan kelompok lima (K5) merupakan kelompok perlakuan yang diberikan dosis ekstrak buah okra yang berbeda yaitu $0,375 \mathrm{mg} / 100 \mathrm{gBB}$ tikus, $0,75 \mathrm{mg} / 100 \mathrm{gBB}$ tikus, dan 1,5 $\mathrm{mg} / 100 \mathrm{gBB}$ tikus (Tabel 1).

Tabel 1. Pengukuran seluruh kelompok

\begin{tabular}{|c|c|c|c|c|c|c|c|c|c|c|c|c|}
\hline & \multirow{2}{*}{$\begin{array}{c}\text { Hewan } \\
\text { uji }\end{array}$} & \multirow{2}{*}{ HO } & \multirow{2}{*}{ H1 } & \multicolumn{9}{|c|}{ H2 } \\
\hline & & & & m-0 & $\mathrm{m}-\mathbf{3 0}$ & $m-60$ & $\mathrm{~m}-90$ & m-120 & j-6 & j-12 & j-18 & $\mathrm{j}-24$ \\
\hline \multirow{4}{*}{$\mathrm{K} 1$} & A.1 & 73 & 129 & 132 & 116 & 92 & 114 & 124 & 102 & 134 & 103 & 89 \\
\hline & A. 2 & 78 & 110 & 131 & 114 & 90 & 133 & 119 & 125 & 132 & 115 & 109 \\
\hline & A. 3 & 79 & 99 & 116 & 124 & 107 & 118 & 120 & 120 & 98 & 88 & 122 \\
\hline & Rerata & 77 & 113 & 126 & 118 & 96 & 122 & 121 & 116 & 121 & 102 & 107 \\
\hline \multirow{4}{*}{$\mathrm{K} 2$} & B. 1 & 66 & 196 & 206 & 181 & 197 & 174 & 166 & 114 & 54 & 99 & 155 \\
\hline & B. 2 & 68 & 226 & 226 & 221 & 186 & 214 & 175 & 132 & 66 & 98 & 146 \\
\hline & B. 3 & 72 & 222 & 232 & 241 & 206 & 179 & 176 & 126 & 78 & 102 & 193 \\
\hline & Rerata & 69 & 215 & 221 & 214 & 196 & 189 & 172 & 124 & 66 & 100 & 165 \\
\hline \multirow{4}{*}{ K3 } & C. 1 & 61 & 222 & 223 & 202 & 203 & 189 & 215 & 208 & 179 & 209 & 212 \\
\hline & C. 2 & 61 & 224 & 227 & 192 & 174 & 200 & 205 & 172 & 172 & 205 & 222 \\
\hline & C. 3 & 69 & 199 & 213 & 204 & 180 & 180 & 185 & 156 & 165 & 215 & 206 \\
\hline & Rerata & 64 & 215 & 221 & 199 & 186 & 190 & 202 & 179 & 172 & 210 & 213 \\
\hline \multirow{4}{*}{ K4 } & D.1 & 74 & 235 & 200 & 247 & 198 & 184 & 183 & 189 & 195 & 220 & 216 \\
\hline & D. 2 & 62 & 215 & 211 & 221 & 207 & 174 & 176 & 168 & 165 & 209 & 210 \\
\hline & D. 3 & 56 & 217 & 223 & 242 & 240 & 177 & 175 & 158 & 140 & 185 & 211 \\
\hline & Rerata & 64 & 222 & 211 & 237 & 215 & 178 & 178 & 172 & 167 & 205 & 212 \\
\hline \multirow{4}{*}{ K5 } & E.1 & 67 & 253 & 220 & 276 & 264 & 237 & 194 & 174 & 198 & 242 & 226 \\
\hline & E. 2 & 72 & 200 & 218 & 223 & 225 & 205 & 190 & 170 & 161 & 183 & 202 \\
\hline & E. 3 & 66 & 274 & 264 & 215 & 255 & 199 & 218 & 258 & 240 & 217 & 214 \\
\hline & Rerata & 68 & 242 & 234 & 238 & 248 & 214 & 201 & 201 & 200 & 214 & 214 \\
\hline
\end{tabular}




\section{BAHASAN}

Penelitian ini dilakukan dengan menggunakan hewan uji berupa 15 ekor tikus wistar yang diinduksi aloksan sebagai zat yang memberikan kondisi diabetik eksperimental dan diberikan ekstrak buah okra sebagai zat penurun gula darah. Peningkatan kadar gula darah pada tikus ini memiliki karaketeristik seperti Diabetes Melitus tipe 1 pada manusia. ${ }^{6}$

Hasil pengukuran kadar glukosa darah pada kelompok kontrol negatif yang hanya diberikan aquades didapatkan kadar glukosa darah rata-rata masih dalam batas normal yaitu $50-135 \mathrm{mg} / \mathrm{dL}^{7}$ Aquades merupakan air murni hasil penyulingan yang hampir murni tidak mengandung mineral. Glukosa darah pada ketiga tikus masih dalam batas normal karena tidak diinduksi aloksan.

Pada 4 kelompok lain diberikan perlakuan awal dengan pemberian aloksan. Aloksan diberikan untuk merusak sel $\beta$ pankreas, dengan tujuan membuat tikus penelitian dalam kondisi DM. Setelah pemberian aloksan dapat dilihat bahwa glukosa darah mengalami peningkatan melebihi glukosa darah normal secara signifikan. $^{6}$

Hasil pengukuran kadar glukosa pada kelompok kontrol postitif yang diinduksi analog insulin novomix kadar glukosa darah didapatkan menurun dikarenakan analog insulin yang berikatan dengan reseptor insulin untuk meningkatkan ambilan glukosa darah dan menghambat produksi glukosa hepar sehingga dapat menurunkan kadar gula darah. Kadar glukosa darah mengalami peningkatan pada jam ke-24 diduga karena durasi kerja dari analog insulin telah habis. Insulin Novomix memiliki efek maksimal yaitu antara 1-4 jam setelah injeksi, dan durasi kerja kurang dari 24 jam. $^{20,21}$ Pada hasil penelitian didapatkan glukosa darah menurun dan baru mencapai batas normal pada jam ke-6. Hal ini kemungkinan disebabkan karena tikus mengalami stress, sehingga glukosa darah tidak turun dengan cepat. $^{22}$
Hasil pengukuran kadar glukosa pada kelompok yang diberikan ekstrak buah okra didapatkan menurun tetapi tidak mencapai kadar glukosa darah normal. Hal ini kemungkinan disebabkan oleh karena dosis yang diberikan kurang, pemberian ekstrak yang dilakukan hanya satu kali dan waktu hanya dilakukan sampai jam ke-24, sehingga efek penurunan kadar glukosa belum terlihat.

Selain itu penurunan glukosa darah yang tidak optimal kemungkinan juga dapat disebakan oleh karena buah yang digunakan tidak berkhasiat menurunkan glukosa darah. Pada penelitian sebelumnya telah dilakukan uji efek menggunakan daun okra. Hasil penelitian tersebut menunjukkan bahwa daun okra memiliki khasiat untuk menurunkan glukosa darah. Berdasarkan hasil penelitian ini, dapat disimpulkan bahwa buah okra tidak memiliki khasiat menurunkan glukosa darah.

\section{SIMPULAN DAN SARAN}

Berdasarkan hasil penelitian dapat disimpulkan bahwa ekstrak buah Okra dengan dosis $75 \mathrm{mg} / \mathrm{kgBB}$ tikus, 150 $\mathrm{mg} / \mathrm{kgBB}$ tikus, dan $300 \mathrm{mg} / \mathrm{kgBB}$ tikus tidak mempunyai efek menurunkan kadar glukosa darah tikus yang diinduksi dengan aloksan. Perlu dilakukan penelitian lebih lanjut menggunakan dosis ekstrak buah okra yang lebih besar. Perlu dilakukan penelitian lebih lanjut dengan menambah jumlah pemberian ekstrak buah okra. Perlu dilakukan penelitian lebih lanjut dengan waktu pengukuran yang lebih lama.

\section{DAFTAR PUSTAKA}

1. Inzucchi $S$, Bergenstal $R$, Fonseca $V$, Gregg E, Mayer B, Spollet G, et al . Diagnosis and Classification of Diabetes Mellitus. American Diabetes Association. 2010. h.1.

2. Misnadiarly. Diabetes Mellitus : Gangren, Ulcer, Infeksi. Edisi ke-1. Jakarta: PPO; 2006. h.117.

3. Nugroho IA. Lokakarya Nasional Tanaman Obat Indonesia 2010 [internet]. Available from: http://forplan.or.id/. Diakses 23 
Agustus 2016.

4. Gemede HF, Ratta N, Haki GD, Woldegiorgis AD, Beyene $\mathrm{F}$. Nutritional Quality and Health Benefits of Okra (Abelmoschus esculentus). Global Journal of Medical Research. 2014;14:2

5. Shin JW, Seol IC, Son CG. Interpretation of Animal Dose and Human Equivalent Dose for Drug Development. The Journal of Korean Oriental Medicine. 2010;31:1-7.

6. Ankur R, Sahjad A. Alloxan induced diabetes:Mechanism and Effects. International Journal of Research in Pharmaceutical and Biomedical Sciences. 2013. h.1 [Internet].
Available

from:

http://www.ijrpbsonline.com. Diakses 2 September 2016

7. Gad SC. Animal Models in Toxicology. Edisi ke-2. New York : Taylor \& Francis. 2006. h.152-96.

8. Product information insulin aspart. Available from: http://www.novonordisk.com.au. Diakses 16 November 2016

9. Novomix 30 Flexpen. Diunduh dari : http://omedicine.info. Diakses 20 November 2016

10.s9 Factors That Affect How Insulin Works. Available from: http://www.health.com. Diakses 24 November 2016 